\title{
Variety, time of harvest and conditions during growing season have impact on red clover isoflavone content
}

\author{
Eeva Mustonen ${ }^{1}$, Mikko Tuori², Päivi Kurki ${ }^{3}$, Mika Isolahti ${ }^{4}$, Juhani Taponen ${ }^{1}$, Aila Vanhatalo² \\ ${ }^{1}$ Department of Production Animal Medicine, Faculty of Veterinary Medicine, University of Helsinki, Paroninkuja 20, \\ 04920 Saarentaus, Finland \\ ${ }^{2}$ Department of Agricultural Sciences, Faculty of Agriculture and Forestry, P.O. Box 28, University of Helsinki, \\ 00014 University of Helsinki, Finland \\ ${ }^{3}$ Natural Resources Institute Finland (Luke), Mikkeli, Lönnrotinkatu 3, 50100 Mikkeli, Finland \\ ${ }^{4}$ Boreal Plant Breeding Ltd., Myllytie 10, 31600 Jokioinen, Finland \\ e-mail: eeva.mustonen@helsinki.fi
}

\begin{abstract}
Red clover (Trifolium pratense L.) is the predominant legume used in northern European agriculture. Official red clover variety trials are conducted by Natural Resources Institute Finland (Luke) to determine the value of field crop varieties. The trials used for the current analysis were conducted in Luke units in southern Finland (Mikkeli) and northern Finland (Ruukki) in two consecutive years. Plant samples for isoflavone analyses were collected from four varieties grown as four replicates and harvested twice during both growing seasons. The four main isoflavones biochanin A, genistein, daidzein and formononetin were analysed using high performance liquid chromatography. Total phytoestrogen content in the varieties varied in the range of $11.2-14.8 \mathrm{mg} \mathrm{g}^{-1} \mathrm{dry}$ matter (DM). The variety and the time of harvest had most effect on the isoflavone, especially formononetin, contents of red clover. A more northern growing area and challenging weather conditions were associated with increased isoflavone concentrations.
\end{abstract}

Key words: red clover, variety, isoflavone, daidzein, formononetin, equol

\section{Introduction}

There is growing interest in using forage legumes for ruminant feeding in organic as well as in conventional agriculture. In organic agriculture, inorganic $\mathrm{N}$ fertilizers are not permitted and legumes are used because of their ability to fix atmospheric nitrogen. Red clover (Trifolium pratense L.) is the major forage legume available for silage production in northern Europe. When legume plants are used, the need of $\mathrm{N}$ fertilizers diminishes in grassland based production systems (Halling et al. 2002, Halling et al. 2004, Vanhatalo et al. 2009).

Red clover is valuable ruminant feed for its crude protein and digestible fibre contents. In comparison with grass silage, red clover silage can stimulate higher dry matter intake and milk yield in dairy cows (Dewhurst et al. 2003, Bertilsson and Murphy 2003, Vanhatalo et al. 2006, Johansen et al. 2017). In addition, replacing grass silage with red clover silage can lead to desirable changes in milk fatty acid composition (Dewhurst et al. 2003, Bertilsson and Murphy 2003, Vanhatalo et al. 2006, Vanhatalo et al. 2007). Red clover diets promote growth and increase live weight gain in ewes and in lambs (Fraser et al. 2004, Moorby et al. 2004, Speijers et al. 2005, Graves et al. 2012).

Red clover contains isoflavones such as biochanin A, genistein, daidzein and formononetin (Kallela et al. 1988, Saloniemi et al. 1995, Sarelli et al. 2003). Isoflavones can have affinity towards oestrogen receptor, but the affinity varies greatly and in most cases high concentrations are needed (Pfitscher et al. 2008). In the rumen biochanin A is demethylated, first to genistein and thereafter to para-etylfenol and fenolacid, which do not have oestrogenic effects. Formononetin is converted first to daidzein and then to equol and its by-products. Physiologically the most important product of metabolism is equol (Shutt and Braden 1968, Cox and Braden 1974, Lundh et al. 1990). In addition, isoflavones have antioxidant capacity, for example genistein has been shown to inhibit significantly the replication of bovine herpes virus 1, which causes infectious bovine rhinotracheitis (Akula et al. 2002). Genistein also inhibited bovine viral diarrhoea virus (Lecot et al. 2005).

High intake on isoflavones, especially formononetin, can affect the fertility of sheep. Fertility problems in sheep are best known in Australia and New Zealand where sheep graze all year around (Adams 1995). In cattle, however, only very few case reports on possible fertility effects have been published (Thain 1966, Kallela et al. 1984). Sheep seem to be more susceptible to isoflavone phytoestrogens, even though metabolism of isoflavones is similar in sheep and cattle (Lundh 1990, Lundh et al. 1990). 
Intake of isoflavones affects milk composition. The first assessment of isoflavonoids in bovine milk was by King and others in Australia (King et al. 1998). They found the highest concentrations, $293 \mathrm{ng} \mathrm{ml}^{-1}$ equol, in samples from Western Australia, where prevalence of clover varieties is high. Similarly high equol concentrations were found in France (Antignac et al. 2003, Antignac et al. 2004). Recent research on the isoflavonoid concentrations in dairy milk associated with different silages and pasture has been done mainly in the Nordic countries (Purup et al. 2004, Hoikkala et al. 2007, Andersen et al. 2008, Steinshamn et al. 2008, Mustonen et al. 2009, Höjer et al. 2012).

The objective of this research was to study whether the variety, conditions during various growing seasons, growing site and time of harvest affect isoflavone content of red clover. It was hypothesized that isoflavone contents differ between the varieties and are higher in the northern rather than southern sites and that challenging weather conditions can increase the isoflavone concentrations of the varieties.

\section{Materials and methods}

\section{General site description and management}

According to the regulations of the Ministry of Agriculture and Forestry in Finland, the official variety trials are conducted by Natural Resources Institute Finland (Luke) to determine the value of field crop varieties (Anonymous 2004). The variety trials are performed in accordance with quality programme. During 2003 and 2004 variety trials for red clover were performed in two research sites, in Mikkeli $\left(61^{\circ} 41^{\prime} \mathrm{N}, 27^{\circ} 12^{\prime} \mathrm{E}\right)$ and in Ruukki $\left(64^{\circ} 41^{\prime} \mathrm{N} 25^{\circ} 04^{\prime} \mathrm{E}\right)$ (Kangas et al. 2010, Kangas et al. 2011). Four varieties of red clover Betty, Saija, Ilte and Jokioinen were studied in the official variety trials. The variety Bjursele was not included in the official trial; instead it was grown as border crop of the experimental fields. All four varieties were cultivated in four different plots at the two sites used. The first cut of the experimental plots and the border crop were harvested when five percent of inflorescences were visible (Järvi et al. 1998) in July (8-10 July 2003, 12-15 July 2004). The second cut were harvested at the end of August (22 August-1 September 2003) or at the beginning of September (2-7September 2004). Two parallel samples from each red clover plots were collected. The variety tests were done during the 2003 growing season and repeated in 2004. Plant samples for isoflavone analyses were collected at the same time from the harvests as the samples for the official variety trial. Samples were stored frozen in $-18^{\circ} \mathrm{C}$ until analyses.

\section{Weather at the sites}

The length of growing seasons, the effective accumulated temperatures and precipitations for the years 2003 and 2004 at both sites Mikkeli and Ruukki are presented in the Table 1. The growing season was longer, amount of precipitation bigger and the effective accumulated temperatures lower during the year 2004 when compared to year 2003 (Hutila 2015).

Table 1. Weather at the sites

\begin{tabular}{|c|c|c|c|c|c|c|}
\hline & Year & $\begin{array}{l}\text { Beginning of } \\
\text { the growing } \\
\text { season }^{1}\end{array}$ & $\begin{array}{c}\text { End of the growing } \\
\text { season }^{1}\end{array}$ & $\begin{array}{l}\text { Length of } \\
\text { the growing } \\
\text { season days }\end{array}$ & $\begin{array}{c}\text { The effective } \\
\text { accumulated } \\
\text { temperature }{ }^{\circ} \mathrm{C}^{2}\end{array}$ & $\begin{array}{c}\text { The } \\
\text { accumulated } \\
\text { precipitation } \\
\mathrm{mm}^{2}\end{array}$ \\
\hline Mikkeli Airport & 2003 & 5th May & 12th October & 161 & 1283 & 377 \\
\hline Mikkeli Airport & 2004 & 29th April & 8th October & 163 & 1247 & 389 \\
\hline $\begin{array}{l}\text { Ruukki } \\
\text { Siikajoki, Revonlahti }\end{array}$ & 2003 & 5th May & 11th October & 160 & 1220 & 271 \\
\hline $\begin{array}{l}\text { Ruukki } \\
\text { Siikajoki, Revonlahti }\end{array}$ & 2004 & 16th April & 7th October & 175 & 1126 & 451 \\
\hline
\end{tabular}

${ }^{1}$ Effective day degrees; ${ }^{2}$ During growing season 


\section{Analytical procedures}

The quantitative high performance liquid chromatography (HPLC) analysis of herbage samples was presented in detail by Mustonen et al. (2006). In brief, $5 \mathrm{~g}$ of melted herbage was chopped and crushed and $25 \mathrm{ml}$ of water was added. After shaking and incubation for $60 \mathrm{~min}$ at ambient temperature, $10 \mathrm{ml}$ of $3.5 \mathrm{M}$ hydrogen chloride $(\mathrm{HCl})$ and $80 \mathrm{ml}$ of ethanol were added to hydrolyse the isoflavone compounds. The mixture was shaken and heated to boiling and cooled. Hydrolysed samples were stored in a fridge at $+6{ }^{\circ} \mathrm{C}$. Extraction of herbage samples was done with $50 \mathrm{ml}$ of ethanol and repeated three times by shaking for $1 \mathrm{~min}$. The herbage sample, container and funnel were rinsed with $100 \mathrm{ml}$ of ethanol and the combined ethanol extracts filtered through a Buechner funnel (filter paper Whatman 40). The extract was evaporated into a $20 \mathrm{ml}$ volume and transferred into a $50 \mathrm{ml}$ volumetric flask and filled to mark with ethanol. After $48-72 \mathrm{~h}$ storage in a fridge, the ethanolic herbage extract was filtered $(0.45$ $\mu \mathrm{m}$ GHP Acrodisc GF-filter) and dilutions were prepared into $10 \mathrm{ml}$ volumetric flasks. Concentrations of external standards (genistein, daidzein, biochanin A, coumestrol and formononetin in ethanol) were 0.4-12.5 $\mu \mathrm{g} \mathrm{ml}^{-1}$. Each calibration curve used for quantification was characterized by a coefficient of determination $\left(R^{2}\right)$ better than 0.999 . Stock solution concentration was $25 \mathrm{\mu g} \mathrm{ml}^{-1}$. Samples were analysed using two different HPLC detectors, ultraviolet (UV) visible and/or fluorescence. Isoflavones and metabolites were identified using authentic reference compounds. The analytical conditions were a linear gradient between $46 \% \mathrm{MeOH} /$ water and $100 \%$ methanol for 23 $\mathrm{min}$, post time $8 \mathrm{~min}$, flow $1 \mathrm{ml} / \mathrm{min}$, injection volume $10 \mu \mathrm{l}$. The eluent $\mathrm{MeOH} /$ aqueous trifluoroacetic acid was $\mathrm{pH}$ 3, UV detection at $262 \mathrm{~nm}$ and FLEX at $254 \mathrm{~nm}$ and EM $465 \mathrm{~nm}$. Daidzein, genistein and biochanin A were analysed with UV and coumestrol and formononetin with fluorescence detector.

\section{Statistical analyses}

Experimental design was a completely randomized block design with four blocks (replicates) at both experimental sites. The herbage crop was harvested twice during summer and the trial was repeated the following year using the same blocks. Data collected were subjected to mixed model variance analysis, using the MIXED procedure of Statistical Analysis System (SAS Institute Inc, Cary, NC, USA) to identify significant treatment effects and interactions. Arithmetical mean values for isoflavones were calculated for both growing season (the years 2003 and 2004), for sites (Mikkeli and Ruukki), harvests (July and September) and varieties (Betty, Saija, Ilte and Jokioinen). The statistical model included year, experimental site, harvests and varieties and all their interactions. Replicate (year* experimental site) was a random factor in the model. Residuals for the entire data set were checked for normality and outliers using the UNIVARIATE procedure of SAS. The data comprised 128 observations for daidzein and genistein, but as for formononetin, biochanin A and total isoflavones two observations were considered outliers and excluded from the analysis. In the variance analysis, natural logarithmic data transformations were used. Post-anova comparisons between the treatments were made using a Tukey's test. Significant differences among treatment were considered at $p<0.05$.

\section{Results}

The mean isoflavone concentrations of red clover as influenced by the growing year, experimental site, time of harvest and variety used are presented in Table 2, and results from the analysis of variance in Table 3 . The main isoflavones in red clover varieties were formononetin, varying in range of 5.95-7.89 $\mathrm{mg} \mathrm{g}^{-1}$ in DM, followed by biochanin A varying in range of 3.66-6.07 $\mathrm{mg} \mathrm{g}^{-1}$ in DM. The respective concentrations of genistein, $0.49-0.55 \mathrm{mg}$ $\mathrm{g}^{-1}$ in DM and daidzein, $0.23-0.30 \mathrm{mg} \mathrm{g}^{-1}$ in DM, were considerably smaller than the concentrations of the main isoflavones. No coumestrol was found from the samples. The total isoflavone content was as highest, $14.8 \mathrm{mg} \mathrm{g}^{-1}$ $\mathrm{DM}$, in variety Ilte, which also had the highest formononetin concentration of all the varieties studied, $7.89 \mathrm{mg}$ $\mathrm{g}^{-1} \mathrm{DM}$. Concentrations of total isoflavones including formononetin and biochanin A were significantly higher in northern than in southern Finland, and at the later (2. cut) than earlier (1. cut) harvest time as well as under the challenging growing conditions of the year 2004. This was evidenced with smaller effective accumulated temperatures and greater precipitation of the year 2004 in comparison to the previous year 2003. 
Table 2. The mean isoflavone concentrations for red clover, $\mathrm{mg} \mathrm{g}^{-1}$ dry matter. Natural logarithmic transformed means are presented in parentheses.

\begin{tabular}{|c|c|c|c|c|c|c|c|c|c|c|c|}
\hline & \multicolumn{2}{|c|}{ Year } & \multicolumn{2}{|c|}{$\begin{array}{c}\text { Experimental } \\
\text { site }\end{array}$} & \multicolumn{2}{|c|}{$\begin{array}{l}\text { Harvest } \\
\text { number }\end{array}$} & \multicolumn{4}{|c|}{ Variety $^{1}$} & \multirow[t]{2}{*}{ SE } \\
\hline & 2003 & 2004 & $\begin{array}{l}\text { South- } \\
\text { Finland }\end{array}$ & $\begin{array}{l}\text { North- } \\
\text { Finland }\end{array}$ & $\mathrm{H} 1$ & $\mathrm{H} 2$ & Betty & Saija & Ilte & Jokioinen & \\
\hline Daidzein & $\begin{array}{c}0.31 \\
(-1.20)\end{array}$ & $\begin{array}{c}0.23 \\
(-1.51)\end{array}$ & $\begin{array}{c}0.25 \\
(-1.44)\end{array}$ & $\begin{array}{c}0.30 \\
(-1.27)\end{array}$ & $\begin{array}{c}0.29 \\
(-1.29)\end{array}$ & $\begin{array}{c}0.25 \\
(-1.42)\end{array}$ & $\begin{array}{c}0.30 \\
(-1.25)^{d}\end{array}$ & $\begin{array}{c}0.23 \\
(-1.52)^{c}\end{array}$ & $\begin{array}{c}0.31 \\
(-1.22)^{d}\end{array}$ & $\begin{array}{c}0.25 \\
(-1.43)^{c}\end{array}$ & (0.18) \\
\hline Genistein & $\begin{array}{c}0.51 \\
(-0.70)\end{array}$ & $\begin{array}{c}0.53 \\
(-0.65)\end{array}$ & $\begin{array}{c}0.52 \\
(-0.67)\end{array}$ & $\begin{array}{c}0.52 \\
(-0.67)\end{array}$ & $\begin{array}{c}0.54 \\
(-0.63)\end{array}$ & $\begin{array}{c}0.50 \\
(-0.72)\end{array}$ & $\begin{array}{c}0.55 \\
(-0.61)^{b}\end{array}$ & $\begin{array}{c}0.51 \\
(-0.70)^{\mathrm{ab}}\end{array}$ & $\begin{array}{c}0.53 \\
(-0.65)^{\mathrm{ab}}\end{array}$ & $\begin{array}{c}0.49 \\
(-0.72)^{a}\end{array}$ & (0.15) \\
\hline Formononetin & $\begin{array}{c}6.26 \\
(1.82)\end{array}$ & $\begin{array}{c}7.40 \\
(1.98)\end{array}$ & $\begin{array}{c}6.60 \\
(1.86)\end{array}$ & $\begin{array}{c}7.06 \\
(1.93)\end{array}$ & $\begin{array}{c}5.92 \\
(1.76)\end{array}$ & $\begin{array}{c}7.74 \\
(2.03)\end{array}$ & $\begin{array}{c}7.15 \\
(1.94)^{d}\end{array}$ & $\begin{array}{c}5.95 \\
(1.77)^{\mathrm{ac}}\end{array}$ & $\begin{array}{c}7.89 \\
(2.05)^{\mathrm{e}}\end{array}$ & $\begin{array}{c}6.32 \\
(1.83)^{\mathrm{bc}}\end{array}$ & $(0.10)$ \\
\hline Biochanin A & $\begin{array}{c}4.13 \\
(1.38)\end{array}$ & $\begin{array}{c}5.22 \\
(1.61)\end{array}$ & $\begin{array}{c}4.39 \\
(1.44)\end{array}$ & $\begin{array}{c}4.95 \\
(1.55)\end{array}$ & $\begin{array}{c}4.31 \\
(1.41)\end{array}$ & $\begin{array}{c}5.03 \\
(1.58)\end{array}$ & $\begin{array}{c}3.66 \\
(1.26)^{c}\end{array}$ & $\begin{array}{c}4.51 \\
(1.48)^{d}\end{array}$ & $\begin{array}{c}6.07 \\
(1.77)^{\mathrm{e}}\end{array}$ & $\begin{array}{c}4.44 \\
(1.46)^{d}\end{array}$ & $(0.17)$ \\
\hline Total & $\begin{array}{c}11.2 \\
(2.40)\end{array}$ & $\begin{array}{c}13.4 \\
(2.57)\end{array}$ & $\begin{array}{c}11.7 \\
(2.44)\end{array}$ & $\begin{array}{c}12.8 \\
(2.53)\end{array}$ & $\begin{array}{c}11.1 \\
(2.38)\end{array}$ & $\begin{array}{c}13.5 \\
(2.59)\end{array}$ & $\begin{array}{c}11.6 \\
(2.43)^{c}\end{array}$ & $\begin{array}{c}11.2 \\
(2.40)^{c}\end{array}$ & $\begin{array}{c}14.8 \\
(2.68)^{d}\end{array}$ & $\begin{array}{c}11.5 \\
(2.43)^{c}\end{array}$ & $(0.11)$ \\
\hline
\end{tabular}

${ }^{1}$ Superscripts indicate differences $\left({ }^{\mathrm{a}, \mathrm{b}} p=0.05 ;{ }^{\mathrm{c}, \mathrm{d}, \mathrm{e}} p<0.001\right.$ ) between the four red clover varieties; SE= standard error

Table 3. $p$-values from the analysis of variance of the isoflavone concentration of four red clover varieties grown for two years at two experimental sites and harvested twice during growing season

\begin{tabular}{|c|c|c|c|c|c|}
\hline & Daidzein & Genistein & Formononetin & Biochanin A & Isoflavone total \\
\hline Year & 0.002 & NS & $<0.001$ & $<0.001$ & $<0.001$ \\
\hline Experimental site & 0.05 & NS & 0.002 & 0.006 & 0.001 \\
\hline Year $\times$ Site & NS & 0.018 & NS & 0.02 & NS \\
\hline Variety & $<0.001$ & 0.023 & $<0.001$ & $<0.001$ & $<0.001$ \\
\hline Harvest & $<0.001$ & 0.003 & $<0.001$ & $<0.001$ & $<0.001$ \\
\hline Year $\times$ Harvest & $<0.001$ & 0.003 & NS & NS & NS \\
\hline Site $\times$ Harvest & 0.002 & NS & NS & 0.001 & 0.027 \\
\hline Variety $\times$ Harvest & NS & NS & $<0.001$ & 0.007 & 0.005 \\
\hline Year $\times$ Variety $\times$ Harvest & NS & NS & 0.016 & NS & 0.042 \\
\hline Site $\times$ Variety $\times$ Harvest & NS & 0.027 & NS & NS & NS \\
\hline
\end{tabular}

In the analysis of variance, there were significant year * variety * harvest interactions for total isoflavone (Fig. 1) and formononetin (Fig. 2) concentrations suggesting that increase in the isoflavone contents due to late cut owing to poor weather conditions in the year 2004 was greater with some varieties such as Betty than with other varieties. The same seemed to be true also for the border crop variety Bjursele although it was not included in the statistical analysis. 


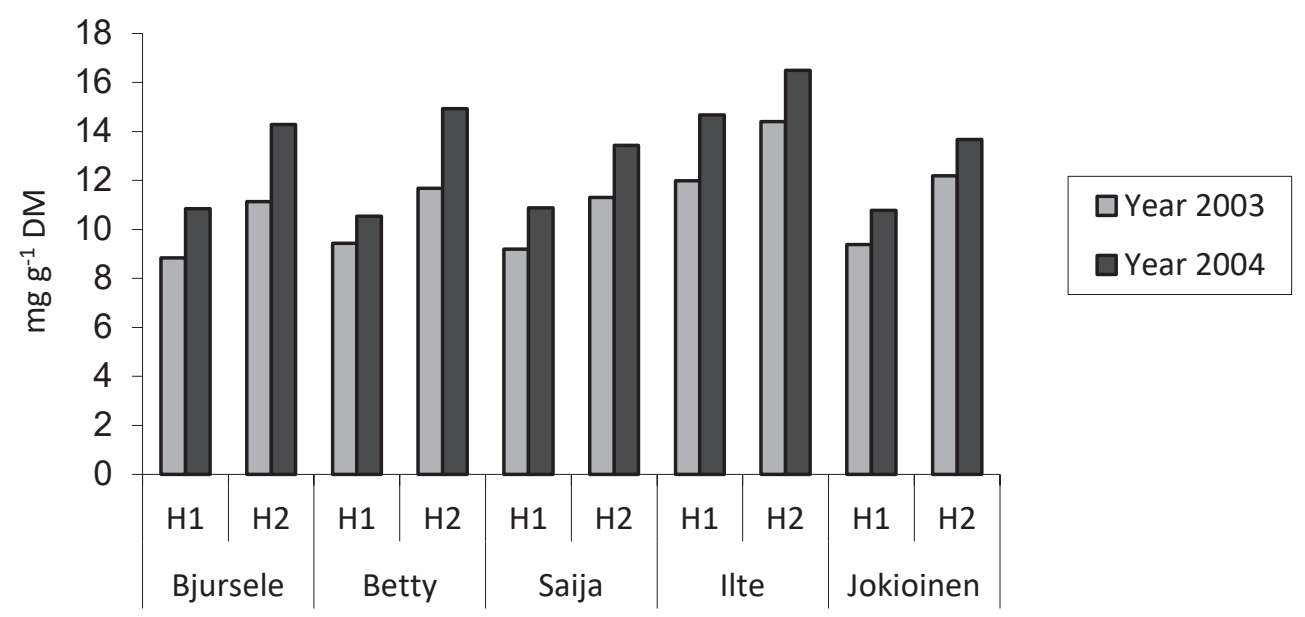

Fig. 1. The total isoflavone concentration ( $\mathrm{mg} \mathrm{g}^{-1} \mathrm{dry}$ matter) for different red clover varieties at first (H1) and second (H2) harvest in 2003 and 2004

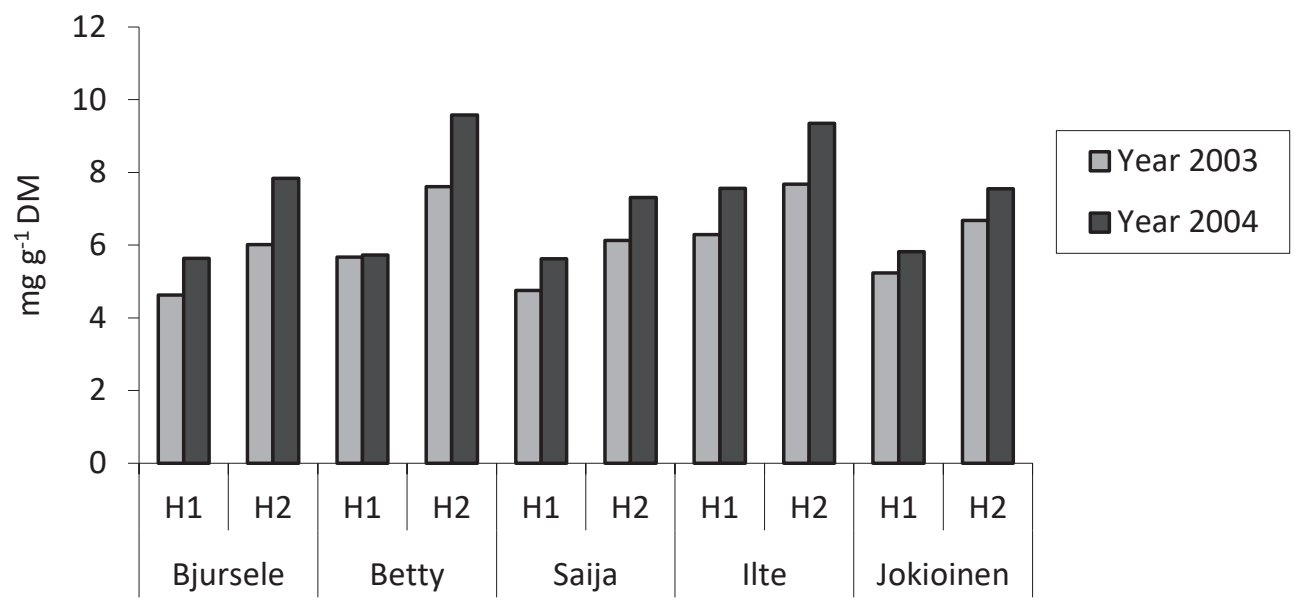

Fig. 2. The formononetin content ( $\mathrm{mg} \mathrm{g}^{-1}$ dry matter) for different red clover varieties at first (H1) and second (H2) harvest in 2003 and 2004

\section{Discussion}

The isoflavone contents found in this study are in line with those from previous studies, for example, total isoflavone content in Finnish red clover silages were at $10-25 \mathrm{mg} \mathrm{g}^{-1}$ in DM and formononetin content at 7-10 mg $\mathrm{g}^{-1}$ in DM (Kallela et al. 1988, Saloniemi et al. 1995). In the Nordic countries the total isoflavone content of red clover can range from 5-25 mg g${ }^{-1}$ DM (Pettersson et al. 1984, Kallela et al. 1988, Saloniemi et al. 1995, Sarelli et al. 2003, Steinshamn et al. 2008, Andersen et al. 2009, Bernes et al. 2017). In previous studies it was established that isoflavone content is high in young crops, then declines during the middle of the growing season and rises again with advancing growth and can be even higher for later than earlier cuts (Kallela et al. 1988, Saloniemi et al. 1995). Moreover, it was reported that when the growing time is shortest, i.e. red clover is harvested again shortly after the previous cut, the formononetin content is highest (Mustonen et al. 2009).

Our results showing great variation in isoflavone content between the various varieties confirm results reported earlier. Red clover varieties differ significantly in isoflavone content, which means that genotype has an impact on isoflavone content (Kallela et al. 1988, Sivesind et al. 2005, Tsao et al. 2006, Saviranta et al. 2008, Bernes et al. 2017). Even if there are environmental effects like soil, stand age and harvest time, the variety choice will influence most on isoflavonoid amounts (Sivesind et al. 2005). 
E. Mustonen et al. (2018) 27: 102-109

Temperature affects isoflavone levels, in a way that the lower the temperature the higher the formononetin content (McMurray et al. 1986). In an earlier study, higher isoflavone levels were detected in northern Finland compared with southern areas (Kallela et al. 1988), as recorded in this study between southeast Mikkeli and northwest Ruukki. There are also other factors that can affect isoflavone content. Nitrogen fertilizers can reduce the isoflavone content in swards (Kallela et al. 1987), but shortage of phosphate increased isoflavone amounts (Butler et al. 1967), especially formononetin content (McMurray et al. 1986). Elevated ozone levels, as well as biotic and abiotic stress factors, affect the roots by elevating isoflavone concentrations (Saviranta et al. 2008, Saviranta et al. 2010).

In agreement with our results the harvest time and season have influenced isoflavone content (McMurray et al. 1986, Kallela et al. 1987, Kallela et al. 1988, Sivesind et al. 2005, Booth et al. 2006). There is abundant production of isoflavones during spring and early summer when the growth of plants is fastest, and then production declines by midsummer (Kallela et al. 1980, McMurray et al. 1986,). In aftermath, the content increases and is high especially when compared with the age of the growth (Kallela et al. 1987). It has been shown that shorter growing periods of red clover resulted in higher silage formononetin content (Mustonen et al. 2009). In all parts of the plants formononetin diminishes as the plant matures. For the regrowth, the earlier the clover is harvested the higher are the isoflavone concentrations, and with the longest regrowth period the formononetin content is the lowest (McMurray et al. 1986).

Red clover leaves have the highest formononetin and biochanin A concentration; in stems and flowers formononetin predominates (Sivesind et al. 2005, Tsao et al. 2006, Saviranta et al 2008). Total levels of isoflavones are highest in leaves, intermediate in stems and lowest in flowers (Wu et al. 2003, Sivesind et al. 2005, Tsao et al. 2006). Just at the beginning of flowering the isoflavone content of inflorescences is highest (Sivesind et al. 2005) and declines after budding (Sarelli et al. 2003). For formononetin in leaves and stems, the highest concentrations were detected at the early maturity stage (Sivesind et al. 2005).

In conclusion, our results show that total isoflavone and formononetin concentrations of the present red clover varieties vary a great deal but are in range of concentrations reported previously. The variety and the time of harvest have the major effect on the isoflavone contents of red clover, but also the northerly growing areas and poor weather conditions can increase concentrations. Our results show that high and possibly harmful concentrations for sheep can be formed in northern location with poor weather and certain red clover varieties.

\section{Acknowledgments}

The authors would like to thank Professor Hannu Saloniemi for the help in organizing the experiment and laboratory technician Ilkka Saastamoinen for the isoflavonoids analyzes.

\section{References}

Adams, N.R. 1995. Detection of the effects of phytoestrogens on sheep and cattle. Journal of Animal Science 73: 1509-1515. https://doi.org/10.2527/1995.7351509x

Akula, S.M., Hurley, D.J., Wixon, R.L., Wang, C. \& Chase, C.C.L. 2002. Effect of genistein on replication of bovine herpesvirus type 1. American Journal of Veterinary Research 63: 1124-1128. https://doi.org/10.2460/ajvr.2002.63.1124

Andersen, C., Nielsen, T.S., Purup, S., Kristensen, T., Eriksen, J., Søegaard, K., Sørensen, J. \& Fretté, X.C. 2009. Phyto-oestrogens in herbage and milk from cows grazing white clover, red clover, lucerne or chicory-rich pastures. Animal 3: 1189-1195. https:// doi.org/10.1017/S1751731109004613

Andersen, C., Weisbjerg, M.R., Hansen-Møller, J. \& Sejrsen, K. 2008. Effect of forage on the content of phyto-oestrogens in bovine milk. Animal 3: 617-622. https://doi.org/10.1017/S1751731108003698

Anonymous. Maa- ja metsätalousministeriö asetus nro 51/2004. Cited 13 June 2015. http://www.finlex.fi/data/normit/1953604051fi.pdf

Antignac, J., Cariou, R., Le Bizec, B. \& Andre, F. 2004. New data regarding phytoestrogens content in bovine milk. Food Chemistry 87: 275-281. https://doi.org/10.1016/j.foodchem.2003.12.013

Antignac, J.P., Cariou, R., Le Bizec, B., Cravedi, J.P. \& Andre, F. 2003. Identification of phytoestrogens in bovine milk using liquid chromatography/electrospray tandem mass spectrometry. Rapid Communications in Mass Spectrometry 17: 1256-1264. https:// doi.org/10.1002/rcm.1052

Bertilsson, J. \& Murphy, M. 2003. Effects of feeding clover silages on feed intake, milk production and digestion in dairy cows. Grass and Forage Science 58: 309-322. https://doi.org/10.1046/j.1365-2494.2003.00383.x

Bernes, G., Höjer, A. \& Gustavsson, A.-M. 2017. Innehåll av fytoöstrogen i olika rödklöversorter. Rapport 2017:1. Umeå. Institution för norrländsk jordbruksvetenskap, Sveriges lantbruksuniversitet. 28 p. Cited 18.6.2018. https://pub.epsilon.slu.se/14507/1/ bernes_g_et_al_170718.pdf. (in Swedish). 
Booth, N.L., Overk, C.R., Yao, P., Totura, S., Deng, Y., Hedayat, A.S., Bolton, J.L., Pauli, G.F. \& Farnsworth, N.R. 2006. Seasonal variation of red clover (Trifolium pratense L., Fabaceae) isoflavones and estrogenic activity. Journal of Agricultural and Food Chemistry 54: 1277-1282. https://doi.org/10.1021/jf052927u

Butler, G.W., Steemers, M.A.T. \& Wong, E. 1967. The effect of nitrogen, phosphorus, and potassium supply on the isoflavone content of leaves of red clover (Trifolium pratense L.). Journal of New Zealand Agricultural Research 10: 312-315. https://doi.org/1 $0.1080 / 00288233.1967 .10425138$

Cox, R.I. \& Braden, A.W. 1974. The metabolism and physiological effects of phyto-oestrogens in livestock. Proceedings of Australian Society of Animal Production 10: 122-129.

Dewhurst, R.J., Fisher, W.J., Tweed, J.K.S. \& Wilkins, R.J. 2003. Comparison of grass and legume silages for milk production. 1. Production responses with different levels of concentrate. Journal of Dairy Science 86: 2598-2611. https://doi.org/10.3168/jds. S0022-0302(03)73855-7

Fraser, M.D., Speijers, M.H.M., Theobald, V.J., Fychan, R. \& Jones, R. 2004. Production performance and meat quality of grazing lambs finished on red clover, lucerne or perennial ryegrass swards. Grass and Forage Science 59: 345-356. https://doi.org/10.1111/ j.1365-2494.2004.00436.x

Graves, M.E., McLean, N., Jones, G. \& Martin, R.C. 2012. Pasture and sheep performance response to sod-seeding red clover (Trifolium pratense L.) or white clover (Trifolium repens L.) into naturalized pastures in eastern Canada. Animal Feed Science and Technology 177: 7-14. https://doi.org/10.1016/j.anifeedsci.2012.06.006

Halling, M.A., Hopkins, A., Nissinen O., Paul C., Tuori, M. \& Soelter, U. 2002. Forage legumes -productivity and composition, In: Wilkins, R.J. \& Paul, C. (eds.) Legume silages for Animal Production- LEGSIL. Braunschweig, Germany: Landbauforschung Voelkenrode Sonderheft. p. 5-15.

Halling, M.A., Topp, C.F.E. \& Doyle, C.J. 2004. Aspects of the productivity of forage legumes in Northern Europe. Grass and Forage Science 59: 331-344. https://doi.org/10.1111/j.1365-2494.2004.00435.x

Hoikkala, A., Mustonen, E., Saastamoinen, I., Jokela, T., Taponen, J., Saloniemi, H. \& Wähälä, K. 2007. High levels of equol in organic skimmed Finnish cow milk. Molecular Nutrition \& Food Research 51: 782-786. https://doi.org/10.1002/mnfr.200600222

Hutila, A. 2015. Finnish Meteorological Institute. Cited 13 July 2015. http://en.ilmatieteenlaitos.fi/weather-in-recent-years

Höjer, A., Adler, S., Purup, S., Hansen-Møller, J., Martinsson, K., Steinshamn, H. \& Gustavsson, A. 2012. Effects of feeding dairy cows different legume-grass silages on milk phytoestrogen concentration. Journal of Dairy Science 95: 4526-4540. https://doi. org/10.3168/jds.2011-5226

Johansen, M., Søegaard, K. Lund, P. \& Weisbjerg, M. R. 2017. Digestibility and clover proportion determine milk production when silages of different grass and clover species are fed to dairy cows. Journal of Dairy Science 100: 8861-8880. https://doi. org/10.3168/jds.2017-13401

Järvi, A., Mattila, I., Mäkelä, L., Rahkonen, A., Salo, Y., Vuorinen, M., Öfversten, J. \& Kangas, A. 1998. Virallisten lajikekokeiden suoritusohjeet. Maatalouden tutkimuskeskuksen julkaisuja. Sarja B. 1998: 61.

Kallela, K. 1980. The estrogenic effect of silage fodder. Nordisk Veterinarmedicin 32: 480-486.

Kallela, K., Heinonen, K. \& Saloniemi, H. 1984. Plant oestrogens; the cause of decreased fertility in cows. A case report. Nordisk Veterinarmedicin 36: 124-129.

Kallela, K., Saastamoinen, I. \& Huokuna, E. 1987. Variations in the content of plant oestrogens in red clover-timothy grass during the growing season. Acta Veterinaria Scandinavica 28: 255-262.

Kallela, K., Saastamoinen, I., Huokuna, E. \& Hakkola, H. 1988. Variation in plant oestrogen content between certain red clover cultivars in northern and southern Finland. Suomen Eläinlääkärilehti 94: 287-291.

Kangas, A., Niskanen, M., Salo, Y., Vuorinen, M., Jauhiainen, L. \& Nikander, H. 2010. Virallisten lajikekokeiden tulokset 2003-2010: Results of official variety trials 2003-2010. Cited 13 July 2015. http://jukuri.mtt.fi/handle/10024/438196

Kangas, A., Niskanen, M., Salo, Y., Vuorinen, M., Jauhiainen, L. \& Nikander, H. 2011. Virallisten lajikekokeiden tulokset 2004-2011. Cited 13 July 2015. http://jukuri.luke.fi/handle/10024/438201

King, R.A., Mano, M.M. \& Head, R.J. 1998. Assessment of isoflavonoid concentrations in Australian bovine milk samples. Journal of Dairy Research 65: 479-489. https://doi.org/10.1017/S0022029998002891

Lecot, S., Belouzard, S., Dubuisson, J. \& Rouille, Y. 2005. Bovine viral diarrhea virus entry is dependent on clathrin-mediated endocytosis. Journal of Virology 79: 10826-10829. https://doi.org/10.1128/JVI.79.16.10826-10829.2005

Lundh, T.J.O. 1990. Conjugation of the plant estrogens formononetin and daidzein and their metabolite equol by gastrointestinal epithelium from cattle and sheep. Journal of Agricultural and Food Chemistry 38: 1012-1016. https://doi.org/10.1021/jf00094a021

Lundh, T.J., Pettersson, H.I. \& Martinsson, K.A. 1990. Comparative levels of free and conjugated plant estrogens in blood plasma of sheep and cattle fed estrogenic silage. Journal of Agricultural and Food Chemistry 38: 1530-1534. https://doi.org/10.1021/ jf00097a022

McMurray, C.H., Laidlaw, A.S. \& McElroy, M. 1986. The effect of plant development and environment on formononetin concentration in red clover (Trifolium pratense L.). Journal of the Science of Food and Agriculture 37: 333-340. https://doi.org/10.1002/ jsfa.2740370402

Moorby, J.M., Fraser, M.D., Theobald, J.W., Wood, J.D. \& Haresign, W. 2004. The effect of red clover Trifolium pratense formononetin content on liveweight gain, carcass characteristics and muscle equol content of finishing lambs. Animal Science 79: 303-313. https://doi.org/10.1017/S1357729800090160

Mustonen, E., Jokela, T., Saastamoinen, I., Taponen, J., Taponen, S., Saloniemi, H. \& Wähälä, K. 2006. High serum S-equol content in red clover fed ewes: the classical endocrine disruptor is a single enantiomer. Environmental Chemistry Letters 3: 154-159. https://doi.org/10.1007/s10311-005-0023-0 
Mustonen, E., Tuori, M., Saastamoinen, I., Taponen, J., Wähälä, K., Saloniemi, H. \& Vanhatalo, A. 2009. Equol in milk of dairy cows is derived from forage legumes such as red clover. British Journal of Nutrition 102: 1552-1556.https://doi.org/10.1017/ S0007114509990857

Pfitscher, A., Reiter, E. \& Jungbauer, A. 2008. Receptor binding and transactivation activities of red clover isoflavones and their metabolites. Journal of Steroid Biochemistry 112: 87-94. https://doi.org/10.1016/j.jsbmb.2008.08.007

Pettersson, H., Holmberg, T., Kiessling, K.-H. \& Rutqvist, L. 1984. Växtöstrogener i foder och reproduktionsstörningar hos iddisslare. Svensk Veterinärtidning 36: 677-683.

Purup, S., Hansen-Møller, J., Sejrsen, K., Christensen, L.P., Lykkesfeldt, A.E., Leffers, H. \& Skakkebæk, N.E. 2005. Increased phytoestrogen content in organic milk and the biological importance. Cited 13 July 2015. http://www.darcof.dk/enews/jun05/milk.html

Saloniemi, H., Wähälä, K., Nykänen-Kurki, P., Kallela, K. \& Saastamoinen, I. 1995. Phytoestrogen content and estrogenic effect of legume fodder. Proceedings of the Society for Experimental Biology and Medicine 208: 13-17. https://doi.org/10.3181/00379727$208-43825$

Sarelli, L., Tuori, M., Saastamoinen, I., Syrjälä-Qvist, L. \& Saloniemi, H. 2003. Phytoestrogen content of birdsfoot trefoil and red clover: Effects of growth stage and ensiling method. Acta Agriculturae Scandinavica - Section A Animal Science 53: 58-63.

Saviranta, N.M., Anttonen, M.J., von Wright, A. \& Karjalainen, R.O. 2008. Red clover (Trifolium pratense L.) isoflavones: determination of concentrations by plant stage, flower colour, plant part and cultivar. Journal of the Science of Food and Agriculture 88 : 125-132. https://doi.org/10.1002/jsfa.3056

Saviranta, N.M., Julkunen-Tiitto, R., Oksanen, E. \& Karjalainen, R.O. 2010. Leaf phenolic compounds in red clover (Trifolium pratense L.) induced by exposure to moderately elevated ozone. Environmental Pollution 158: 440-446. https://doi.org/10.1016/j. envpol.2009.08.029

Shutt, D.A. \& Braden, A.W.H. 1968. The significance of equol in relation to the oestrogenic responses in sheep ingesting clover with a high formononetin content. Australian Journal of Agricultural Research 19: 545-553. https://doi.org/10.1071/AR9680545

Sivesind, E. \& Seguin, P. 2005. Effects of the environment, cultivar, maturity, and preservation method on red clover isoflavone concentration. Journal of Agricultural and Food Chemistry 53: 6397-6402. https://doi.org/10.1021/jf0507487

Speijers, M.H.M., Fraser, M.D., Theobald, V.J. \& Haresign, W. 2005. Effects of ensiled forage legumes on performance of store finishing lambs. Animal Feed Science and Technology 120: 203-216. https://doi.org/10.1016/j.anifeedsci.2005.02.027

Steinshamn, H., Purup, I.S., Thuen, E. \& Hansen-Møller, J. 2008. Effects of clover-grass silages and concentrate supplementation on the content of phytoestrogens in dairy cow Milk. Journal of Dairy Science 91: 2715-2725. https://doi.org/10.3168/jds.2007-0857

Thain, R.I. 1966. Bovine infertility possibly caused by subterranean clover. Further report and herd histories. The Veterinary Bulletin 36: 199-203.

Tsao, R., Papadopoulos, Y., Yang, R., Young, J.C. \& McRae, K. 2006. Isoflavone profiles of red clovers and their distribution in different parts harvested at different growing stages. Journal of Agricultural and Food Chemistry 54: 5797-5805. https://doi. org/10.1021/jf0614589

Vanhatalo, A., Gäddnäs, T. \& Heikkilä, T. 2006. Microbial protein synthesis, digestion and lactation responses of cows to grass or grass-red clover silage diet supplemented with barley or oats. Agricultural and Food Science 15: 252-267. https://doi. org/10.2137/145960606779216236

Vanhatalo, A., Kuoppala, K., Ahvenjärvi, S. \& Rinne, M. 2009. Effects of feeding grass or red clover silage cut at two maturity stages in dairy cows. 1. Nitrogen metabolism and supply of amino acids. Journal of Dairy Science 92: 5620-5633. https://doi. org/10.3168/jds.2009-2249

Vanhatalo, A., Kuoppala, K., Toivonen, V. \& Shingfield, K.J. 2007. Effects of forage species and stage of maturity on bovine milk fatty acid composition. European Journal of Lipid Science and Technology 109: 856-867. https://doi.org/10.1002/ejlt.200700023

Wu, Q., Wang, M. \& Simon, J.E. 2003. Determination of isoflavones in red clover and related species by high-performance liquid chromatography combined with ultraviolet and mass spectrometric detection. Journal of Chromatography A 1016: 195-209. https://doi.org/10.1016/j.chroma.2003.08.001 